\title{
Hubungan Keseimbangan dan Koordinasi Mata Kaki Terhadap Kemampuan Menggiring Bola dalam Permainan Futsal Klub Karsa Utama Putri Wajo
}

\author{
Muhammad Hasbillah, Herman \\ Program Studi Pendidikan Jasmani, Kesehatan, dan Rekreasi STKIP YPUP Makassar \\ muhammadhasbillah08@gmail.com
}

Received: Januari 2021; Accepted: Februari 2021; Published: Maret 2021

Ed: Maret 2021; 8(1): 67-72

\begin{abstract}
Abstrak
Penelitian ini bertujuan untuk mengetahui hubungan antara keseimbangan terhadap kemampuan menggiring bola, hubungan koordinasi mata kaki terhadap kemampuan menggiring bola, dan hubungan antara keseimbangan dan koordinasi mata kaki terhadap kemampuan menggiring bola dalam permainan futsal Klub Karsa Utama Putri Wajo. Jenis penelitian ini adalah korelasional dengan variabel bebas adalah keseimbangan dan koordinasi mata kaki, sedangkan variabel terikat adalah kemampuan menggiring bola. Populasi dalam penelitian ini adalah pemain klub Karsa Utama Putri Wajo dan sampel yang diambil sebanyak 25 pemain. Teknik penentuan sampel adalah teknik sampling total. Teknik analisis yang digunakan adalah analisis deskriptif, analisis korelasi, analisis regresi. Hasil penelitian menunjukkan bahwa 1) Ada hubungan yang signifikan antara keseimbangan terhadap kemampuan menggiring bola pada pemain klub Karsa Utama Putri Wajo dengan nilai korelasi $(r)=0,738$. 2) Ada hubungan yang signifikan antara koordinasi mata kaki terhadap kemampuan menggiring bola pada pemain klub Karsa Utama Putri Wajo dengan nilai korelasi $(\mathrm{r})=0,553$. 3) Ada hubungan yang signifikan antara keseimbangan dan koordinasi mata kaki terhadap kemampuan menggiring bola pada pemain klub Karsa Utama Putri Wajo dengan nilai korelasi $(\mathrm{R})=0,823$, dan dengan nilai koefisien determinasi $\left(\mathrm{R}^{2}\right)=0,677$ atau sama dengan $67,7 \%$. Dengan demikian dapat disimpulkan bahwa ada hubungan yang signifikan antara keseimbangan dan koodinasi mata kaki terhadap kemampuan menggiring bola dalam permainan futsal Klub Karsa Utama Putri Wajo.
\end{abstract}

Kata Kunci: keseimbangan, koordinasi mata kaki, menggiring bola.

\begin{abstract}
This research aims to determine the relationship between balanced and the ability to dribble, the relationship between eye-foot coordination and the ability to dribble, and the relationship between balanced and eye-foot coordination on the ability todribble in futsal game Karsa Utama Putri Wajo's club. The research was correlational research, with the independent variable was balanced and eye-foot coordination, while the dependent variable was the ability to dribble. The population of theresearch was Karsa Utama Putri Wajo's club players and the sampling technique used was total sampling technique with the total sample was 25 players. The analysis technique used was descriptive analysis, correlation analysis, regression analysis. The results showed that 1)There was a significant relationship between balanced and the ability to dribble in Karsa Utama Putri Wajo's club players with a correlation value $(r)=0,738$. 2) There was asignificant relationship between eye-foot coordination on the ability to dribble in Karsa Utama Putri Wajo's club players with a correlation value $(r)=$ 0,553. 3) There was asignificant relationship between balanced and eye-foot coordination on the ability to dribble in Karsa Utama Putri Wajo's club player swith a correlation value $(r)=0.823$, and a coefficient of determination $\left(R^{2}\right)=0.677$ or equal to $67,7 \%$. Thus, it can be concluded that there is a significant relationship between balanced and coordination of the ankle son the ability to dribble in futsal game of Karsa Utama Putri Wajo's club
\end{abstract}

Keywords: balanced, coordination, dribbling. 


\section{PENDAHULUAN}

Olahraga pada hakekatnya merupakan kegiatan gerak tubuh yang ditandai dengan gerakangerakan tubuh secara ritmis, dan tersusun secara sistematis yang dimaksud untuk memperoleh kebugaran dan kesehatan (Syarifudin, 2011:22).

Permainan Futsal merupakan cabang olah raga permainan yang dimainkan oleh dua regu yang masing-masing regu terdiri dari 5 orang pemain yang satunya adalah penjaga gawang. Futsal merupakan salah satu cabang olahraga yang termasuk dalam permainan bola besar. Cabang olah raga ini asal mulanya dari cabang olah raga sepakbola yang lebih disederhanakan. Ukuran lapangan dan bola yang digunakan lebih kecil dibandingkan sepakbola, begitu pula dengan peraturan permainan yang berbeda. Teknik dasar permainan futsal pun hamper sama dengan teknik dasar sepakbola, teknik dasar futsal yaitu mengumpan (passing), menahan bola (control), mengumpan lambung (chipping), menggiring bola (dribbling), dan menembak (shooting). Permainan futsal ini dapat dimainkan oleh anak-anak, orang dewasa, laki-laki dan saat ini futsal juga banyak diminati oleh kaum hawa.

Untuk bermain futsal dengan baik, pemain harus dibekali dengan kondisi fisik yang baik seperti daya tahan, daya ledak, kecepatan, kekuatan, koordinasi, kelincahan, keseimbangan, kelentukan, dan ketepatan. Salah satu komponen kondisi fisik yang penting untuk dilatih adalah berupa koordinasi. Karena semua teknik dasar permainan futsal memerlukan tingkat koordinasi yang baik. Hal ini disebabkan karena olahraga futsal dimainkan dengan dominan menggunakan salah satu alat gerak dari bagian tubuh yaitu tungkai.

Berdasarkan hasil observasi di klub Karsa Utama Putri Wajo menunjukkan bahwa teknik menggiring bola dalam permainan futsal masih kurang maksimal. Pada saat menggiring bola beberapa pemain sering menabrak lawan dan akhirnya bola dengan mudah direbut oleh lawan. Sebagian juga pemain menggiring bola tidak sesuai dengan arah yang diinginkan sehingga bolanya sering keluar dari lapangan permainan. Menurut Aji (2016:88), untuk mengecoh pemain lawan dalam sebuah permainan futsal, seorang pemain futsal harus memiliki kemampuan dalam menggiring bola. Oleh karena itu diperlukan suatu penelitian untuk memecahkan berbagai masalah tersebut demi meningkatkan kemampuan menggiring bola dalam permainan futsal klub Karsa Utama Putri Wajo. Dalam penelitian ini faktor kondisi fisik yang akan dikaji adalah keseimbangan dan koordinasi mata kaki.

\section{METODE}

Penelitian ini merupakan jenis penelitian korelasi. Menurut Sukardi (2015:166) penelitian korelasi adalah suatu penelitian yang melibatkan tindakan pengumpulan data guna menentukan apakah ada hubungan dan tingkat hubungan antara dua variabel atau lebih.

Menurut Salim dan Hidir (2018:53) studi korelasi ini mempelajari tentang hubungan dua variable atau lebih, yaitu sejauh mana variasi dalam satu variable berhubungan dengan variasi dalam variable lain. Yang bertujuan untuk menguji hipotesis, dilakukan dengan cara mengukur sejumlah variabel dan menghitung keofisien korelasi antar variable-variabel tersebut, agar dapat ditentukan variabel-variabel mana yang berkorelasi.

Metode penelitian yang digunakan adalah metode penelitian kuantitatif. Menurut Salim dan Haidir (2019:22) penelitian kuantitatif diidentifikasikan sebagai proses kerja yang berlangsung secara ringkas, terbatas dan memilah-milah peramsalahan menjadi bagian yang dapat diukur atau dinyatakan dalama angka-angka. 


\section{Variabel penelitian}

Dalam penelitian ini ada dua variabel yang terlibat, yaitu variabel bebas dan variabel terikat Variabel bebas yaitu keseimbangan (x1) dan koordinasi mata kaki(x2), sedangkan variabel terikat yaitu kemampuan menggiring bola (Y).

\section{Populasi dan sampel}

Menurut Sugiyono (2018:80), populasi adalah wilayah generasi yang terdiri atas objek/subjek yang mempunyai kualitas dan karakteristik tertentu yang ditetapkan oleh peneliti untuk dipelajari kemudian ditarik kesimpulannya. Berdasarkan pendapat di atas, maka populasi dalam penelitian ini adalah seluruh individu yang akan dijadikan subjek penelitian dan keseluruhan dari individu itu paling tidak memiliki suatu sifat yang sama. Sehingga mengikutsertakan semua pemain di Klub Karsa Utama Putri Wajo yang berjumlah 25 orang.

Menurut Salim dan Haidir (2019:220) sampel adalah bagian dari populasi yang memiliki ciri-ciri atau sifat-sifat yang sama dan/atau serupa dengan populasinya. Sesuai dengan rumusan tersebut, sampel harus memiliki ciri-ciri atau sifat-sifat yang menggambarkan secara tepat sifatsifat aslinya. Dalam penelitian ini cara pengambilan sampel adalah dengan teknik sampling total. Menurut Sugiyono (2019:155) sampling total adalah teknik pengambilan sampel dimana seluruh anggota populasi dijadikan sampel semua. Hal ini sering dilakukan bila jumlah populasi relatif kecil, kurang dari 30 orang, atau penelitian yang ingin membuat generalisasi dengan kesalahan yang sangat kecil. Jadi sampel yang digunakan dalam penelitian ini adalah 25 orang yang terdiri atas pemain putri.

\section{Teknik pengumpulan data}

Sebagai salah satu prosedur penelitian dan untuk menentukan bagaimana cara memperoleh data mengenai variabel yang ingin diteliti maka digunakan suatu instrumen penelitian. Adapun instrument dalam penelitian ini adalah sebagaiberikut :

1. Tes keseimbangan dinamis (Widiastuti, 2017:164)

2. Tes koordinasi mata kaki (AlbertusFenanlampir ,2015:54)

3. Tes menggiring bola (Halim \& Anwar, 2018:169)

\section{HASIL DAN PEMBAHASAN}

Data yang disajikan berikut adalah data keseimbangan, koordinasi mata kaki, dan data kemampuan menggiring bola.

Tabel 1: Hasil analisis deskriptif

\begin{tabular}{l|c|c|c|}
\hline Hipotesis Statistik & $\begin{array}{c}\text { Keseimbangan } \\
\text { (poin) }\end{array}$ & $\begin{array}{c}\text { Koordinasi Mata Kaki } \\
\text { (poin) }\end{array}$ & $\begin{array}{c}\text { Menggiring Bola } \\
\text { (detik) }\end{array}$ \\
\hline $\mathbf{N}$ & 25 & 25 & 25 \\
\hline Mean & 35,40 & 9,52 & 23,0700 \\
\hline Median & 35,00 & 9,00 & 23,3200 \\
\hline Mode & 30 & 7 & 24,14 \\
\hline Std. Deviation & 10,794 & 3,151 & 2,27816 \\
\hline Variance & 116,500 & 9,927 & 5.190 \\
\hline Range & 35 & 12 & 8,06 \\
\hline Minimum & 15 & 5 & 18.19 \\
\hline Maximum & 50 & 17 & 26,25 \\
\hline Sum & 885 & 238 & 576.76 \\
\hline
\end{tabular}




\section{Uji normalitas data}

Dari hasil uji kolmogorov-simirnov test yang dilakukan diperoleh hasil sebagaimana yang terlampir. Untuk hasil perhitungan dapat dilihat pada tabel rangkuman berikut.

Tabel 2. Rangkuman hasil uji normalitas

\begin{tabular}{c|c|c|c|c}
\hline Variabel & KS-Z & $\mathbf{P}$ & sig/ $\boldsymbol{\alpha}$ & Keterangan \\
\hline keseimbangan $\left(\mathrm{X}_{1}\right)$ & 0,858 & 0,453 & 0,05 & Normal \\
\hline koordinasi mata kaki $\left(\mathrm{X}_{2}\right)$ & 0,740 & 0,643 & 0,05 & Normal \\
\hline Menggiring bola $(\mathrm{Y})$ & 0,780 & 0,577 & 0,05 & Normal \\
\hline
\end{tabular}

\section{Pengujian hipotesis}

a. Hubungan keseimbangan terhadap kemampuan menggiring bola dalam permainan futsal klub Karsa Utama Putri Wajo.

Berdasarkan hasil penelitian yang telah dilakukan di klub Karsa Utama Putri Wajo, hasil analisis korelasi keseimbangan dengan kemampuan menggiring bola dalam permainan futsal disajikan dalam tabel sebagai berikut:

Tabel 3. Hubungan keseimbangan terhadap kemampuan menggiring bola

\begin{tabular}{c|c|c|c|c}
\hline Korelasi & $\mathbf{N}$ & $\mathbf{r}$ & $\mathbf{P}_{\text {value }}$ & Keterangan \\
\hline $\mathbf{X}_{\mathbf{1} . \mathbf{Y}}$ & 25 & $-0,758$ & 0,000 & Siginifikan \\
\hline
\end{tabular}

Berdasarkan hasil pengujian analisis korelasi keseimbangan terhadap kemampuan menggiring bola, diperoleh nilai korelasi $(r)=-0,758$ dengan tingkat probabilitas $(0,000)$ lebih kecil dari $\alpha=0,05$. Dengan demikian dapat disimpulkan bahwa ada hubungan yang signifikan antara keseimbangan terhadap kemampuan menggiring bola dalam permainan futsal klub Karsa Utama Putri Wajo.

Menurut Fenanlampir (2015:165) keseimbangan dinamis adalah kemampuan mempertahankan keadaan seimbang dalam keadaan bergerak, misalnya berlari, berjalan, melambung, dan sebagainya. Setiap atlet menentukan sikap yang berbeda atau akan mengubah sikap tubuhnya sesuai dengan tuntutan olahraganya. Jadi berdasarkan pendapat di atas dapat disimpulkan bahwa keseimbangan memiliki hubungan yang signifikan dengan kemampuan menggiring bola. Semakin bagus keseimbangan seseorang, maka semakin bagus pula kemampuan menggiring bolanya. Keseimbangan yang baik membuat seorang pemain tidak mudah terjatuh pada saat menggiring bola.

b. Hubungan koordinasi mata kaki terhadap kemampuan menggiring bola dalam permainan futsal klub Karsa Utama Putri Wajo

Berdasarkan hasil penelitian yang telah dilakukan di klub Karsa Utama Putri Wajo, hasil analisis korelasi koordinasi mata kaki dengan kemampuan menggiring bola dalam permainan futsal disajikan dalam tabel sebagai berikut: 
Tabel 4. Hubungan koordinasi mata kaki terhadap kemampuan menggiring bola dalam permainan futsal

\begin{tabular}{c|c|c|c|c}
\hline Korelasi & $\mathbf{N}$ & $\mathbf{r}$ & $\mathbf{P}_{\text {value }}$ & Keterangan \\
\hline $\mathbf{X}_{\mathbf{2} . \mathbf{Y}}$ & 25 & $-0,553$ & 0,004 & Siginifikan \\
\hline
\end{tabular}

Berdasarkan hasil pengujian analisis korelasi koordinasi mata kaki terhadap kemampuan menggiring bola, diperoleh nilai korelasi $(r)=-0,553$ dengan tingkat probabilitas $(0,004)$ lebih kecil dari $\alpha=0,05$. Dengan demikian dapat disimpulkan bahwa ada hubungan yang signifikan antara koordinasi mata kaki terhadap kemampuan menggiring bola dalam permainan futsal klub Karsa Utama Putri Wajo.

Menurut Atmojo (2010:62), koordinasi merupakan kemampuan untuk secara bersamaan melakukan berbagai tugas gerak secara mulus dan akurat. Kemampuan seorang pemain dalam menggring bola dibutuhkan koordinasi mata kaki yang baik. Berdasarkan pendapat di atas, koordinasi mata kaki memiliki hubungan yang signifikan dengan kemampuan menggiring bola. Seseorang yang memiliki koordinasi mata kaki yang baik, akan lebih efektif pada saat menggiring bola dalam permainan futsal. Dengan koordinasi mata kaki yang baik, seorang pemain tidak akan mudah berbenturan dengan pemain lawan pada saat menggiring bola.

c. Hubungan koordinasi mata kaki dan keseimbangan terhadap kemampuan menggiring bola dalam permainan futsal klub Karsa Utama Putri Wajo

Berdasarkan hasil penelitian yang telah dilakukan di klub Karsa Utama Putri Wajo, hasil analisis regresi keseimbangan dan koordinasi mata kaki dengan kemampuan menggiring bola dalam permainan futsal disajikan dalam tabel sebagai berikut:

Tabel 5: Hubungan keseimbangan dan koordinasi mata kaki terhadap kemampuan menggiring bola dalam permainan futsal

\begin{tabular}{c|c|c|c|c|c|c}
\hline Korelasi & $\mathbf{N}$ & $\mathbf{R}$ & $\mathbf{R}^{\mathbf{2}}$ & $\mathbf{F}$ & $\mathbf{P}_{\text {value }}$ & Keterangan \\
\hline $\mathbf{X}_{\mathbf{1 .}} \mathbf{X}_{\mathbf{2}} \mathbf{Y}$ & 25 & 0,823 & 0,677 & 23.084 & 0,000 & Siginifikan \\
\hline
\end{tabular}

Berdasarkan hasil pengujian analisis regresi keseimbangan dan koordinasi mata kaki terhadap kemampuan menggiring bola, diperoleh nilai regresi $(\mathrm{R})=0,823$ dengan tingkat probabilitas $(0,000)$ lebih kecil dari $\alpha=0,05$. Dengan demikian dapat disimpulkan bahwa ada hubungan yang signifikan antara koordinasi mata kaki terhadap kemampuan menggiring bola dalam permainan futsal klub Karsa Utama Putri Wajo. Nilai koefisien determinasi (R2) sebesar $0,677 \times 100 \%=67,7 \%$. Berdasarkan hasil tersebut bahwa ada hubungan antara koordinasi mata kaki dan keseimbangan secara bersama-sama terhadap kemampuan menggiring bola dalam permainan sepakbola klub Karsa Utama Putri Wajo sebesar 67,7\% dan sisanya 32,3\% dipengaruhi oleh beberapa faktor lain. Seseorang yang memiliki keseimbangan dan koordinasi mata kaki yang baik, akan lebih mudah melakukan teknik dasar menggiring bola dalam permainan futsal.

\section{KESIMPULAN}

1. Ada hubungan keseimbangan terhadap kemampuan menggiring bola dalam permainan futsal klub Karsa Utama Putri Wajo

2. Ada hubungan koordinasi mata kaki terhadap kemampuan menggiring bola dalam permainan futsal klub Karsa Utama Putri Wajo 
3. Ada hubungan antara keseimbangan dan koordinasi mata kaki secara bersama-sama terhadap kemampuan menggiring bola dalam permainan futsal klub Karsa Utama Putri Wajo

\section{DAFTAR PUSTAKA}

Aji, Sukma, 2016. Buku Olahraga Paling Lengkap. Pamulang - Ilmu

Fananlampir, Albertus. 2015. Tes \& Pengukuran Dalam Olahraga. Yogyakarta: CV ANDI OFFSET

Halim, Nur Ichsan. 2018. Tes dan Pengukuran Dalam Bidang Keolahragaan. Makassar: Badan Penerbit Universitas Negeri Makassar.

Ismaryati. 2018. Tes dan Pengukuran Olahrga. Jawa Tengah: Penerbitan dan Pencetakan UNS (UNS Press)

Isnanto, Anung Hendra, 2019. Seri Olahraga Futsal. Gamping Sleman: Sentra Edukasi Media

Maryati. 2012. Mengenal Olahraga Futsal. Jakarat Timur: Percetakan dan Penerbitan PT BalaiPustaka (Persero)

Mulyono, M, Asriady. 2017. Buku Pintar Futsal. Jakarta Timur: Anugrah

Sugiyono. 2018. Metode Penelitian: Kualitatif, Kuantitatif, dan R\&D: Alfabeta.

Widiastuti. 2017. Tes dan Pengukuran Olahrga. Jakarta: PT Rajagrafindo Persada 